\title{
Gray Scale Inversion in Digital Image for Measurement of Tooth Length
}

\author{
Matheus Lima OLIVEIRA ${ }^{1}$ \\ Marcela Lacerda VIEIRA ${ }^{1}$ \\ Adriana Dibo CRUZ ${ }^{2}$ \\ Frab Norberto BÓSCOLO ${ }^{1}$ \\ Solange Maria de ALMEIDA ${ }^{1}$ \\ ${ }^{1}$ Department of Oral Diagnosis, Piracicaba Dental School, UNICAMP - University of Campinas, Campinas, SP, Brazil
2Department of Specific Formation, Area of Radiology, Dental School,
UFF - Fluminense Federal University, Nova Friburgo, RJ, Brazil
}

The aim of this study was to assess the applicability of gray scale inversion in performing digital linear endodontic measurements. Standardized digital images were taken of 40 extracted human permanent single-rooted teeth with K-files size 15 placed at different lengths in the root canal, using the CDR Wireless ${ }^{\circledR}$ digital system. All images were treated with Positive, a digital tool that inverts the grayscale value. Eight radiologists measured the distance between the lower limit of the rubber stop and the tip of the file on both original and positive images. After 15 days, they repeated this procedure in 50\% of the image samples. The intra- and inter-examiner agreement was analyzed by intraclass correlation test, and the comparison between the two image groups and the actual lengths by the Student's t-test $(\alpha=0.05)$. Intra- and inter-examiner evaluation showed high reproducibility $(r>0.95)$ of both original and positive images. No statistically significant differences $(p>0.05)$ were found between measurements performed on original and positive images, but both differed significantly from the actual lengths $(\mathrm{p}<0.05)$. Gray scale inversion has low applicability in measuring endodontic files, since it did not improve the accuracy of measurements.

Key Words: software, digital dental radiography, Endodontics, root canal length determination.

\section{INTRODUCTION}

The emergence of digital intraoral radiographic systems has made available a new perspective regarding the quality of radiographic images in dental offices. These digital systems have several advantages over analogue radiographic film (1). Coupled with the development of information technology, digital radiography also attracts dentists by its ability to enhance acquired images. Such enhancement features indicate a potential resource for an improved image quality, resulting in reduced retakes. Currently, there are digital radiographic imaging systems with three types of intraoral image receptors: charge-coupled device (CCD), complementary metal oxide semiconductor (CMOS) and photostimulable phosphor plates (PSP) (2). The CDR Wireless ${ }^{\circledR}$ digital imaging system (Schick Technologies Inc., Long Island City, NY, USA) is manufactured with a wireless CMOS image receptor. This technology used a radio frequency transmission and provides direct and instant viewing.

Periapical radiographs are essential during the entire endodontic treatment. An appropriate intervention requires detailed knowledge of the internal arrangement of the tooth and precision in measuring the length of root canals $(3,4)$. Importantly, caution is needed in detecting anatomical variation of the root apex because it influences on canal instrumentation (5). It is believed that digital measurement is more accurate than measuring with an endodontic ruler on a radiograph, and increases the chance of a successful endodontic treatment (6).

Because the dentist has available a wide variety of diagnostic tools, comparative studies are critical to indicate which tools contribute to a better diagnosis. Among the image enhancement possibilities offered by the software applications, there is a tool known as "positive" (henceforth, Positive). This tool inverts the

Correspondence: Matheus Lima Oliveira, Departamento de Diagnóstico Oral, Faculdade de Odontologia de Piracicaba, UNICAMP, Caixa Postal 52, 13414-903 Piracicaba, SP, Brasil. Tel/Fax: +55-19-2106-5327. e-mail: matheusoliveira@hotmail.com 
image grayscale, changing the pixels of low value (dark) to high value (bright) and vice versa. The aim of this study was to assess the applicability of gray scale inversion in performing digital linear endodontic measurements.

\section{MATERIAL AND METHODS}

The study protocol was approved by the institutional Human Ethics Committee (protocol \# 086/2009). Ten phantoms containing 4 extracted human permanent single-rooted teeth mounted in a stone plaster block were used. All of the teeth had standard access cavities and the record of their length value from a previous study (7). In an effort to simulate the periodontal ligament space and the trabecular bone, the root of each tooth was coated with a layer of wax and the plaster was mixed with powdered rice in a ratio of 1:1.

Dental endodontic K-files size 15 (Maillefer Instruments $\mathrm{CH}$ 1338, Ballaigues, Switzerland) were placed at lengths ranging 0 to $2 \mathrm{~mm}$ from the apical limit. Root instrumentation up to $2 \mathrm{~mm}$ short from the apical limit ensures $94 \%$ endodontic treatment success (8). These lengths were chosen at random and without a relation to the length of the teeth. All data were recorded on a Microsoft Excel for Mac 2011 spreadsheet.

With the aid of an acrylic holder, both the teeth and the sensor of the CDR Wireless ${ }^{\circledR}$ digital imaging system were positioned according to the paralleling technique, with the same geometric factors in all radiographic exposures. The source-object and object-sensor distances were fixed at $35 \mathrm{~mm}$ and $8 \mathrm{~mm}$, respectively. The latter distance is resulting from the plaster block thickness around the roots of the teeth, such as in a clinical trial. The X-ray beam was focused perpendicularly to the sensor and the teeth, and a 25-mm-thick acrylic sheet was placed between the $\mathrm{x}$-ray tube and the teeth to simulate soft tissue scatter. A 10-mm length orthodontic wire was fixed on the sensor surface, serving as a calibration control for each image.

The radiographic exposures were made with the dental X-ray unit GE 1000 (General Electric Company, Milwaukee, WI, USA), set at $70 \mathrm{kVp}, 10 \mathrm{~mA}$ and 0.2 $\mathrm{s}$ and the images were stored as 8-bit TIFF files. All images were treated with Positive. Thus, two groups of images were created: original and positive (Fig. 1).

In a quiet and low-light setting, using a 15 -inch liquid crystal display computer monitor with 1024 x 768 pixels resolution and 32 bits, 8 radiologists evaluated the original and positive images. In a training session, the evaluators were taught to use the CDR DICOM software for Windows 3.0.1, and the evaluation method was established. The method of evaluation is the measuring of the distance between the lower limit of the rubber stop and the tip of the file using the digital ruler. The positive images were evaluated 1 week after the evaluation of the original images. Fifty percent of both original and positive images were reevaluated in a single session 15 days following the positive image's evaluation, in order to test intra- and inter-examiner agreement. All measurements done by evaluators were first calibrated to the known reference length $(10 \mathrm{~mm})$ of the orthodontic wire using the distance calibration tool.

Statistical analysis was performed with the SPSS Statistics v. 17.0 program (SPSS Inc. Chicago, IL, USA). The level of significance was set at 0.05 . Intraclass correlation coefficient was used to evaluate the intraand inter-examiner reliability response pattern. After exploratory data analysis, the measurements between the original and positive images, and the actual lengths were compared by Student's t-test with repeated measures.

\section{RESULTS}

Intra- and inter-examiner evaluation showed high reproducibility $(r>0.95)$ with a narrower confidence interval in the inter-examiner evaluation of both original and positive images. The positive images showed the highest and lowest reproducibility on intra- and interexaminer evaluation, respectively (Table 1).

In Table 2, the mean values of the lengths between the original and positive images were not significantly different $(p>0.05)$, but both differed significantly $(p<0.05)$ from the actual lengths with higher values. The
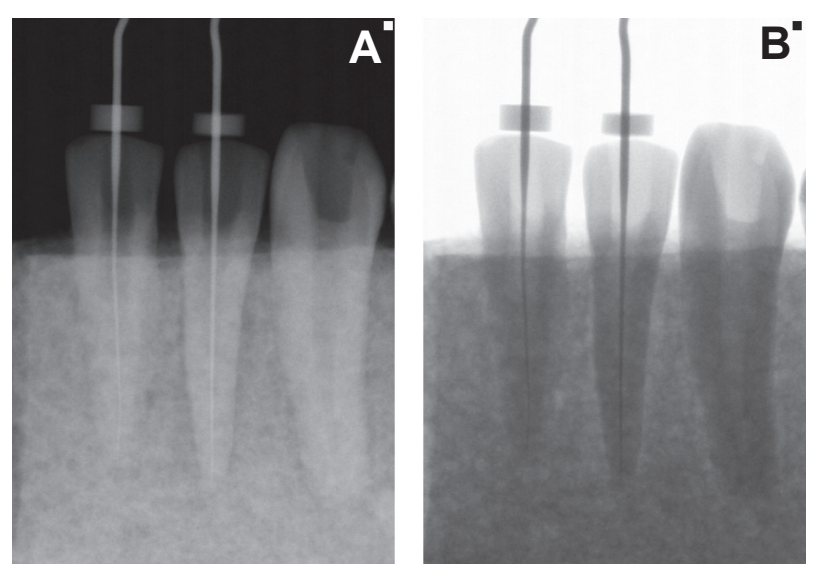

Figure 1. Digital radiographic images. Original(A) and Positive(B).. 
actual lengths showed the highest standard deviation.

\section{DISCUSSION}

The research concerning digital imaging systems has shown that the diagnostic value of enhancement tools provided by software applications is still controversial. Because of the broad availability of enhancement modalities, studies assessing their clinical applications are frequently developed (9). The present study found no significant difference between endodontic file lengths measured in original and positive CMOS images, although both of them have differed from the actual lengths. The present findings agree with those of a previous study that compared the validity of gray scale inversion, with regard to the measurement of endodontic file lengths using Digora storage phosphor plate images (6). Effects of gray scale inversion have also been evaluated in the examination of the periodontium. Kamburoğlu et al. (10) detected no differences in diagnostic outcomes of vertical root fracture. Nevertheless, even without being significantly different, grayscale-inverted images revealed an improvement on the detection of internal root resorption (11).

Recent studies have shown great performance of electronic apex locators $(12,13)$. However, the most common method to determine working length combines knowledge of root lengths, tactile discrimination, assessment of a preoperative radiograph and a radiograph taken with files placed in the root canal (14). In the present study, endodontic files were introduced in the root canal according to the method proposed by Ingle (15). Tooth length was obtained from a previous study (7) in which, after an initial film-based radiograph, the distance between the incisal border and the apical root was measured.

Studies determining file lengths in the root canal have been performed previously $(6,7,14,16)$. This measurement does not address the exact

Table 1. Intra-and inter-examiner reproducibility means and minimum-maximum values of the original and positive images.

\begin{tabular}{lcccc}
\hline Image & Analysis & Mean & Minimum & Maximum \\
\hline \multirow{2}{*}{ Original } & Intra-examiner & 0.964 & 0.959 & 0.971 \\
& Inter-examiner & 0.952 & 0.935 & 0.965 \\
\multirow{2}{*}{ Positive } & Intra-examiner & 0.967 & 0.955 & 0.969 \\
& Inter-examiner & 0.951 & 0.937 & 0.969 \\
\hline
\end{tabular}

clinical procedure during an endodontic treatment. However, it allows evaluating both the effectiveness of the radiographic system to reproduce the actual measurements and the accuracy of the examiners in identifying the tip of the file.

The obtained results showed a response pattern of intra- and inte-examiner analysis very close to 1.0 with a very narrow confidence interval. This reveals high reproducibility of both original and positive images, and uniformity of the evaluators' agreement. All evaluators involved in this study responded favorably towards the positive images. In another study, wherein the evaluators could use 4 different digital tools for tooth length determination, very few evaluators made use of Positive (17). The efficacy of enhancement tools has been described to depend on the evaluator's skills and experience, which makes digital image enhancement a subjective diagnostic tool $(11,15)$.

The mean values of the digital measurements overestimated the actual lengths in $0.4 \mathrm{~mm}$. This may be explained by the inherent magnification of the parallelism technique. Although a 10-mm long orthodontic wire has been used as a calibration control on the sensor surface, the object-sensor distance was set at $8 \mathrm{~mm}$. The divergent nature of the $\mathrm{x}$-ray beam associated with such distance may have allowed image magnification. Additionally, as in a clinical trial, the actual lengths were obtained measuring the actual file with an endodontic ruler and showed higher standard deviation than the original and positive images. This procedure might not have been as accurate as digital measurement because it does not provide readouts with three decimal places. The difficult visualization of the file tip should also be considered, given its small diameter. Though statistically significant, this overestimation is presumably clinically irrelevant. Factors such as file size, image receptor, exposure time, secondary radiation, density differences, the pattern of root and trabecular

Table 2. Mean values of file lengths (in $\mathrm{mm}$ ) and standard deviation (S.D.) in the original and positive images, and the actual lengths.

\begin{tabular}{cl}
\hline Source & Mean (S.D.) \\
\hline Original image & $23.0(2.61)^{\mathrm{a}}$ \\
Positive image & $23.0(2.63)^{\mathrm{a}}$ \\
Actual lengths & $22.6(2.65)^{\mathrm{b}}$ \\
\hline
\end{tabular}

Mean values followed by different letters differ significantly by paired Student's t-test $(\mathrm{p}<0.05)$. 
bone may influence the determination of the tip of the file in the radiographic images (8). Despite the availability of digital enhancement features, the radiographic technical principles should be strengthened as extremely important in obtaining a satisfactory radiograph.

In conclusion, gray scale inversion did not interfere in the measurement accuracy of endodontic file length in a CMOS digital x-ray system. Hence, the use of this digital enhancement tool is at the discretion of the evaluator.

\section{RESUMO}

O objetivo deste estudo foi avaliar a aplicabilidade da inversão da escala de cinza na realização de mensurações endodônticas lineares digitais. Quarenta dentes unirradiculares humanos extraídos foram radiografados com limas $\mathrm{K}$ tamanho 15 posicionadas no canal radicular em diferentes comprimentos, usando o sistema digital CDR Wireless ${ }^{\circledR}$. Todas as imagens foram tratadas com Positive, uma ferramenta digital que inverte os valores da escala de cinza. Oito radiologistas mediram a distância entre o limite inferior do stop de borracha e a ponta da lima endodôntica nas imagens originais e positivas. Após quinze dias, eles repetiram esse procedimento em $50 \%$ da amostra. A concordância intra- e interobservador foi analisada pelo teste de correlação intraclasse e a comparação entre os dois grupos de imagem e os valores reais, pelo teste t-Student $(\alpha=0,05)$. A análise intra- e interobservador apresentou elevada reprodutibilidade $(r>0,95)$ das imagens original e Positive. Não foi encontrada diferença $(p>0,05)$ entre as medidas realizadas nas imagens original e positiva, mas ambas diferiram dos valores reais $(p<0,05)$. A inversão da escala de cinza tem baixa aplicabilidade na realização de mensuração endodôntica, considerando que as medidas não se apresentaram mais acuradas.

\section{ACKNOWLEDGEMENTS}

The authors wish to gratefully acknowledge the help from Mr. Christopher Wenell for reviewing the manuscript.

\section{REFERENCES}

1. Wenzel A. A review of dentists' use of digital radiography and caries diagnosis with digital systems. Dentomaxillofac Radiol 2006:35:307-314.

2. Ludlow JB, Mol A. Digital imaging. In: Oral radiology: principles and interpretation. White SC, Pharoah MJ (Editor). 6th ed. St. Louis, MO: Mosby; 2009. p78-99.

3. Woolhiser GA, Brand JW, Hoen MM, Geist JR, Pikula AA, Pink
FE. Accuracy of film-based, digital, and enhanced digital images for endodontic length determination. Oral Surg Oral Med Oral Pathol Oral Radiol Endod 2005;99:499-504.

4. Ding J, Gutmann JL, Fan B, Lu Y, Chen H. Investigation of apex locators and related morphological factors. J Endod 2010;36:13991403.

5. Souza RA, Sousa YT, de Figueiredo JA, Dantas Jda C, Colombo S, Pécora JD. Influence of apical foramen lateral opening and file size on cemental canal instrumentation. Braz Dent J 2012;23:122-126.

6. Kal BI, Baksi BG, Dündar N, Sen BH. Effect of various digital processing algorithms on the measurement accuracy of endodontic file length. Oral Surg Oral Med Oral Pathol Oral Radiol Endod 2007; 103:280-284.

7. Oliveira ML, Ambrosano GM, Almeida SM, Haiter-Neto F, Tosoni GM. Efficacy of several digital radiographic imaging systems for laboratory determination of endodontic file length. Int Endod J 2011;44:469-473.

8. Friedlander LT, Love RM, Chandler NP. A comparison of phosphor-plate digital images with conventional radiographs for the perceived clarity of fine endodontic files and periapical lesions. Oral Surg Oral Med Oral Pathol Oral Radiol Endod 2002;93:2127.

9. Brüllmann DD, Röhrig B, Sulayman SL, Schulze R. Length of endodontic files measured in digital radiographs with and without noise-suppression filters: an ex-vivo study. Dentomaxillofac Radiol 2011;40:170-176.

10. Kamburoğlu K, Murat S, Pehlivan SY. The effects of digital image enhancement on the detection of vertical root fracture. Dent Traumatol 2010;26:47-51.

11. Kamburoğlu K, Barenboim S, Kaffe I. Comparison of conventional film with different digital and digitally filtered images in the detection of simulated internal resorption cavities-an ex vivo study in human cadaver jaws. Oral Surg Oral Med Oral Pathol Oral Radiol Endod 2008;105:790-797.

12. Paludo L, Souza SL, Só MV, Rosa RA, Vier-Pelisser FV, Duarte MA. An in vivo radiographic evaluation of the accuracy of Apex and iPex electronic Apex locators. Braz Dent J 2012;23:54-58.

13. Vasconcelos BC, Matos Lde A, Pinheiro-Júnior EC, Menezes AS, Vivacqua-Gomes N. Ex vivo accuracy of three electronic apex locators using different apical file sizes. Braz Dent J 2012;23:199204.

14. de Oliveira ML, Pinto GC, Ambrosano GM, Tosoni GM. Effect of combined digital imaging parameters on endodontic file measurements. J Endod 2012;38:1404-1407.

15. Shanmugaraj M, Nivedha R, Mathan R, Balagopal S. Evaluation of working length determination methods: an in vivo/ex vivo study. Indian J Dent Res 2007;18:60-62.

16. Velders XL, Sanderink GC, van der Stelt PF. Dose reduction of two digital sensor systems measuring file lengths. Oral Surg Oral Med Oral Pathol Oral Radiol Endod 1996;81:607-612.

17. Wenzel A, Kirkevang LL. Students' attitudes to digital radiography and measurement accuracy of two digital systems in connection with root canal treatment. Eur J Dent Educ 2004;8:167-171.

Received May 22, 2012

Accepted November 26, 2012 